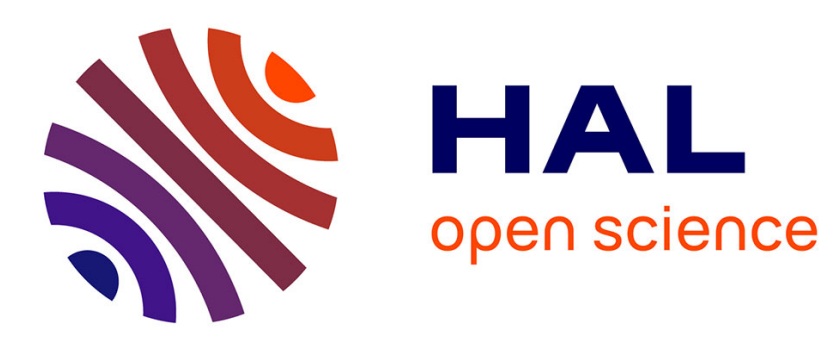

\title{
Effect of copper on the scope for growth of clams () from a farming area in the Northern Adriatic Sea
}

Cristina Munari, Michele Mistri

\section{To cite this version:}

Cristina Munari, Michele Mistri. Effect of copper on the scope for growth of clams () from a farming area in the Northern Adriatic Sea. Marine Environmental Research, 2007, 64 (3), pp.347. 10.1016/j.marenvres.2007.02.006 . hal-00501911

\section{HAL Id: hal-00501911 \\ https://hal.science/hal-00501911}

Submitted on 13 Jul 2010

HAL is a multi-disciplinary open access archive for the deposit and dissemination of scientific research documents, whether they are published or not. The documents may come from teaching and research institutions in France or abroad, or from public or private research centers.
L'archive ouverte pluridisciplinaire HAL, est destinée au dépôt et à la diffusion de documents scientifiques de niveau recherche, publiés ou non, émanant des établissements d'enseignement et de recherche français ou étrangers, des laboratoires publics ou privés. 


\section{Accepted Manuscript}

Effect of copper on the scope for growth of clams (Tapes philippinarum) from a farming area in the Northern Adriatic Sea

Cristina Munari, Michele Mistri

PII:

S0141-1136(07)00039-6

DOI:

10.1016/j.marenvres.2007.02.006

Reference:

MERE 3106

To appear in:

Marine Environmental Research

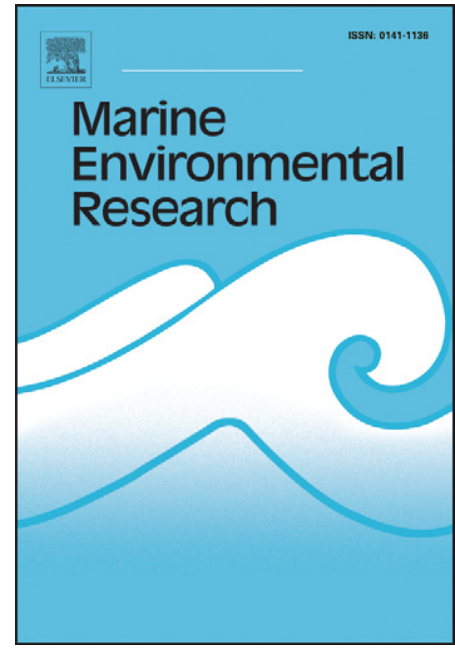

Received Date: $\quad 18$ December 2006

Revised Date: $\quad 20$ February 2007

Accepted Date: $\quad 21$ February 2007

Please cite this article as: Munari, C., Mistri, M., Effect of copper on the scope for growth of clams (Tapes philippinarum) from a farming area in the Northern Adriatic Sea, Marine Environmental Research (2007), doi: 10.1016/j.marenvres.2007.02.006

This is a PDF file of an unedited manuscript that has been accepted for publication. As a service to our customers we are providing this early version of the manuscript. The manuscript will undergo copyediting, typesetting, and review of the resulting proof before it is published in its final form. Please note that during the production process errors may be discovered which could affect the content, and all legal disclaimers that apply to the journal pertain. 
1 Effect of copper on the scope for growth of clams (Tapes 2 philippinarum) from a farming area in the Northern Adriatic Sea.

3

4 Cristina Munari and Michele Mistri ${ }^{*}$

5 Dipartimento di Biologia ed Evoluzione, Università di Ferrara, Via L. Borsari 46, Ferrara 644100, Italy

7

8

9

\section{Abstract}

Copper is currently the most common biocide in antifouling paints. Levels of this metal were measured in the water, particulate matter and sediments from a shellfish farming area in the Sacca di Goro (Northern Adriatic Sea) over one year. With respect to the 1980s, copper environmental level increased two-fold. The release of copper from shellfish farmer boats was also estimated to be $>250 \mathrm{~kg} \mathrm{Cu} \mathrm{y}^{-1}$. Clams Tapes philippinarum were collected in the same area and seasonally exposed to a sublethal $\left(10 \mu \mathrm{gCu} 1^{-1}\right)$ concentration of copper. Physiological traits were significantly affected by copper exposure (scope for growth declined as a result of reduced clearance rate, increased oxygen consumption and a generally lower absorption efficiency). Results of this study are cause for concern for shellfish farming activities at least in Northern Adriatic, where shellfish farming is a monoculture of $T$. philippinarum. A strict interpretation of the precautionary principle might suggest that more rigorous regulatory action to control copper inputs in the field would be justified.

Keywords: Antifouling Paints; Copper; Scope for Growth; Tapes philippinarum; Adriatic Sea.

*Corresponding author. Tel.: +39 0532 291736; fax: +39 0532249761.

E-mail address: michele.mistri@unife.it (M. Mistri). 


\section{Introduction}

2 Copper is essential for biological life, since it is a cofactor of the prion protein and

3 many metalloenzymes, such as cytochrome-c oxidase and copper-zinc superoxide dismutase

4 (White and Rainbow, 1985; Geret et al., 2002). On the other hand, copper at high

5 concentration is extremely toxic: because of its high affinity for thiol groups, copper is able to

6 bind to cysteine with a consequent inactivation of the proteins themselves (Freedman et al.,

7 1989). Copper pollution can arise from mining, brass manufacturing, electroplating and

8 excessive use of copper-based agrochemicals. After the ban of the use of tributyltin as

9 antifouling agent on small $(<25 \mathrm{~m}$ length) boats, copper has become the most common

10 biocide in many antifouling paints (Yebra et al., 2004), and is the predominant toxicant

11 among a number of other biocides (Okamura et al., 2002). Recent investigations have

12 concluded that boat traffic may be a significant source of metal contamination, e.g. through

13 the use of zinc anodes and copper-based antifouling paints (Matthiessen et al., 1999; Karlsson

14 and Eklund, 2004; Schiff et al., 2004). Bivalves accumulate copper in direct proportion to

15 their environmental levels (Roesijadi, 1980). Responses to copper exposure $\left(80-500 \mu \mathrm{g} \mathrm{Cu} \mathrm{l^{- }}\right.$

$16^{1}$ ) have been shown to vary from a reduction in filtration rate (Manley, 1983) to profound

17 effects on protein metabolism (Viarengo et al., 1981), and to reductions in calcium

18 homeostasis (Gnassia-Barelli et al., 1995). At even lower concentration $\left(10 \mu \mathrm{g} \mathrm{Cu}{ }^{-1}\right)$,

19 activities of antioxidant enzymes are reduced (Isani et al., 2003), and growth performance is

20 affected (Sobral and Widdows, 1997).

21 Tapes philippinarum is an exotic species that was deliberately introduced in the 1980s

22 in the Sacca di Goro, a brackish lagoon in the Po River deltaic area (northern Adriatic Sea,

23 Italy), for the relaunch of a mollusc fishery. Today, about half of the bottom of the Sacca di

24 Goro is dedicated to clam culture-based fishery. There is an abundant literature on the

25 ecological characteristics of the species, largely because of its commercial interest (e.g. 
1 Goulletquer and Heral, 1997). However, interactions and energetics of T. philippinarum in the

2 new habitat have only recently been addressed (Mistri, 2004; Sgro et al., 2005a; 2005b). T.

3 philippinarum is both a deposit feeder (i.e. it filters resuspended sediment) and a facultative

4 filter feeder, and is available from farming grounds all year round.

5

Copper, though currently receiving less attention than organotin, will probably face similar restrictive legislation in the future. To date, one developed country, Sweden, has banned all toxic metal antifouling coatings in the Swedish Baltic Sea area (Rittschof, 2001). The main objective of this study was to determine the effect of a sublethal concentration of copper on the energetics of T. philippinarum. Related goals were to determine whether, due to the ban of TBT in antifouling paints, copper contamination in clam farming areas exists, and to estimate the release of copper from shellfish farmers' boats.

\section{Materials and Methods}

\section{Physiological measurements}

Tapes philippinarum were collected from a farming ground $\left(44^{\circ} 48^{\prime} 55.01^{\prime}{ }^{\prime} \mathrm{N}\right.$, $\left.12^{\circ} 18^{\prime} 19.44^{\prime \prime} \mathrm{E}\right)$, and allowed to acclimate to laboratory conditions for one week prior to experiments. Clams were exposed to a sublethal copper concentration of $10 \mu \mathrm{g}^{-1}$, obtained by diluting a stock solution of $1 \mathrm{~g} \mathrm{l}^{-1}$ of $\mathrm{CuCl}_{2}$. There were two copper exposure tanks and two control tanks with 30 clams per tank (in 101 of aerated seawater). Clams were fed daily on a culture of T-Isochrysis (batch: TISO15-1307839; BlueBiotech ${ }^{\circledR}$ Germany). Water was renewed every two days. Tanks and glassware were acid-washed prior to use, and tanks rinsed thoroughly with seawater prior to addition of clams. Sampling times were at $0,2,5,9,14$ and 20 days. At each time point, four randomly chosen clams from each tank (two controls and two treatments) were taken for physiological measurements. Measurement methods are fully described in Sgro et al. (2005a), and followed the procedures outlined by Widdows and Staff 
1 (1997). Briefly, clearance rate was measured in plastic beakers (2 1) of filtered $(0.45 \mu \mathrm{m})$

2 seawater, with two clams per beaker plus one control (without clams). Initial T-Iso

3 concentration was ca. 25000 cells $\mathrm{ml}^{-1}$. Each trial started when the clams started to filter

4 again, i.e. when they extended their siphons. Samples were collected from each beaker every

$520 \mathrm{~min}$ for the duration $(2 \mathrm{~h})$ of the experiment. Clearance rate was measured as the volume of

6 water cleared of chlorophyll-a per unit time, and was related to the dry tissue weight of clams

7 (oven drying of soft parts for $48 \mathrm{~h}$ at $80^{\circ} \mathrm{C}$ ). Oxygen consumption was measured individually

8 in four closed chambers $(200 \mathrm{ml})$ plus one control, with a calibrated OxyGuard ${ }^{\circledR}$ Handy- $\gamma$

9 oxygen electrode, at the start and after $2 \mathrm{~h}$ incubation period. Oxygen consumption was also

10 corrected for the dry weight of clams, and converted to energy equivalents according to

11 Gnaiger (1983): $1 \mu \mathrm{mol} \mathrm{O} \mathrm{O}_{2}=0.456 \mathrm{~J}$. The absorption efficiency was established by the ratio

12 method of Conover (1966), which measures the efficiency with which organic material is

13 absorbed from the ingested food, as the ratio of the fractions of food and faeces lost on ashing

14 ( $4 \mathrm{~h}$ at $450^{\circ} \mathrm{C}$ on pre-weighed Whatman ${ }^{\circledR} \mathrm{GF} / \mathrm{C}$ filters). Faeces were collected from the

15 beakers at the end of each clearance measurement. The scope for growth provides an

16 instantaneous measure of the energy status of the clam: the energy that clams have available

17 for growth and reproduction was finally determined by the equation of Warren and Davis

18 (1967) which is based on the difference between energy absorbed from food consumed and

19 energy losses via respiration. In bivalves, clearance and respiration rates depend on the

20 physiological status, food ration, and to a lesser extent, season and temperature (Bayne et al.,

21 1976; Sobral and Widdows, 2000; Riisgård et al., 2003). The first set of experiments was

22 carried out in November 2003, and then experiments were repeated in March, May and July

23 2004. Physico-chemical water parameters were: temperature $10^{\circ}$ to $25^{\circ} \mathrm{C}$, salinity 26 to 28

24 and $\mathrm{pH} 8.0$ to 8.2 . A total of 480 clams was used (31.5 mm mean shell length $\pm 0.6 \mathrm{SD})$. 
Field surveys focused on sampling of water, sediment and suspended particulate

2 matter (SPM), and covered nine monthly sampling periods from February to December 2004.

3 One fixed station $\left(44^{\circ} 48^{\prime} 55.27^{\prime} \mathrm{N}, 12^{\circ} 18^{\prime} 18.89^{\prime}\right.$ ' $\mathrm{E}$; depth $\left.1.5 \mathrm{~m}\right)$, close to the farming

4 ground, was chosen. At each sampling date, 501 of seawater were collected and immediately

5 vacuum-filtered onto Millipore ${ }^{\circledR}$ HA $0.45 \mu \mathrm{m}$ membranes. Two litres of filtered water were

6 retained and acidified with suprapur $\mathrm{HNO}_{3}$ to 1-2 $\mathrm{pH}\left(2 \mathrm{ml} \mathrm{l}^{-1}\right)$. Membranes with SPM were

7 transferred in weighed bottles and sealed. Sediment samples were collected with a corer; the

8 first $2 \mathrm{~cm}$ of three replicate cores (i.d. $5 \mathrm{~cm}$ ) were retained. All samples were ice-chilled in a

9 cooler on the boat, and received at the laboratory within $2 \mathrm{~h}$ after collection. Water samples were analyzed through DPASV (Differential Pulse Anodic Stripping Voltammetry; Wang, 11 1994) with an AMEL433 instrument. This technique is particularly useful when analyzing 12 seawater. Membranes with SPM were oven dried $\left(100^{\circ} \mathrm{C}\right)$ to constant weight, treated with 13 suprapur $\mathrm{HNO}_{3}$, and mineralized in a microwave oven (Milestone ETHOS 900: $350 \mathrm{w}: 15$ $14 \mathrm{~min}, 400 \mathrm{w}$ : $10 \mathrm{~min})$. After dilution with Milli-Q water, copper analyses were carried out through plasma spectrometry (Perkin-Elmer Optima 3100 XL). Sediment samples were treated and analyzed like SPM samples. Adequate quality assurance/quality control measures

17 were followed in all aspects of the study, and intercalibration exercises were carried out within the TAQC-WFD (ISO/IEC 17025). The analytical procedures were checked using

19 certified reference material (2704 of National Bureau of Standards) and allowed agreement 20 with the certified values higher than $95 \%$.

\section{Estimation of copper inputs from shellfish farmer fleet}

The estimate of copper inputs from boats was conducted calculating the wetted hull area (WHA) of boats, as WHA $=\mathrm{L} x(\mathrm{~B}+\mathrm{D})$, where $\mathrm{L}$ is the length, $\mathrm{B}$ the beam, and $\mathrm{D}$ the 
1 input for all boats (IB) per day, as IB = Number of boats $\mathrm{x}$ WHA $\mathrm{x}$ release rate of copper. The

2 release rate of copper was drawn from literature $\left(6.24 \mu \mathrm{g} \mathrm{cm}^{-2} \mathrm{~d}^{-1}\right.$; Matthiessen et al., 1999).

3

\section{Results}

No mortality occurred during the physiological experiments. Clearance rates were always lower in the copper-exposed clams (Fig. 1). Two-way ANOVAs (Table 1) showed a significant (all $\mathrm{p}<0.001)$ initial decline in clearance rates of exposed clams, which tended to stabilize between the fifth and the eleventh day of exposure, depending on the period of experimentation. Clearance rates also differed with time of exposure (all $\mathrm{p}<0.001$ ). Oxygen consumption was always higher in exposed clams (Fig. 2; all $\mathrm{p}<0.001$ except November, $\mathrm{p}<$ 0.05). Absorption efficiency followed a more complicated pattern (Fig. 3). In two out of four experiments (November and March), a compensation seems evident in the earlier period of exposure, since less food was ingested (lower clearance rates) but it was absorbed more efficiently (higher absorption efficiency). However, all experiments showed a consistent decline in absorption efficiency after 9 d exposure. The results presented in Figures 1, 2 and 3 shows that there was generally a consistent physiological response to $\mathrm{Cu}$ in all four seasonal experiments. Scope for growth was calculated for each measurement period, and was always higher for control clams, independently from different environmental conditions and physiological status of the clams (Fig. 4). In March and July, negative values of the scope for growth indicate that $\mathrm{Cu}$ exposed clams had to use their body reserves to meet metabolic requirements.

Remarkable variations of copper values in the field were found during the study period. Table 2 summarizes copper concentration in water, SPM, and sediments. Briefly, water concentrations ranged between 2 and $7.5 \mu \mathrm{g} \mathrm{Cu} 1^{-1}$; in the SPM between 70 and $287 \mu \mathrm{g}$ $\mathrm{Cu} \mathrm{g}^{-1}$, while in the sediment variations were between 7.5 and $53.5 \mu \mathrm{g} \mathrm{Cu} \mathrm{g}$. 
At Goro, shellfish farmers' boats are quite standard in size, and parameters for the

2 calculation of WHA were: $\mathrm{L}=5 \mathrm{~m}, \mathrm{~B}=1.5 \mathrm{~m}$, and $\mathrm{B}=0.5 \mathrm{~m}$. The fleet consists of about

31200 boats (IREPA, 2003). Thus, the leaching rate of copper from antifouling paints was

4 estimated at $0.75 \mathrm{~kg} \mathrm{Cu} \mathrm{d}^{-1}$, equalling $273 \mathrm{~kg} \mathrm{Cu} \mathrm{yr}^{-1}$. However, this copper input must be

5 considered a very conservative estimate, since it assumes one antifouling treatment per year

6 (most shellfish farmers treat their boats twice a year), and does not consider the recreational

7 fleet (about 200 yachts of various sizes) which is moored all year round in the touristic

8 harbour of Goro.

9

\section{Discussion}

After their ban for the use on small boats and aquaculture, triorganotin antifoulants have been superseded by antifouling products based mainly on copper metal oxides. Although the deleterious effects of excess copper on aquatic biota are known, very few data are available regarding the potential increase in copper concentration following an increase in popularity of such products amongst small boat users. Pre-TBT-ban copper concentration in the water of the Sacca di Goro (1987-1988) was between 0.2 and $1.6 \mu \mathrm{g} \mathrm{Cu} \mathrm{l}^{-1}$ (Fagioli et al., 1991). It seems evident that in the last $15 \mathrm{y}$, the concentration of copper in the water has greatly increased. Of course we can not state whether this is due only to the use of copperbased antifoulants, or to a generalized increase of contamination of the environment (e.g. through the discharge of continental water from the catchment basin of the Po di Volano river). Helland and Bakke (2002), however, reported that during a period of $90 \%$ reduction in the industrial input of copper in a Norwegian estuary, the very high concentrations of copper found were caused by leaching from antifouling paints. We estimated very conservatively a

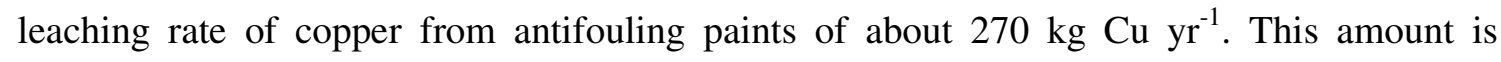
comparable to figures reported in many major marinas and yacht moorings in U.K. 
1 (Matthiessen et al., 1999), which are cause for concern. The sampling site chosen in the Sacca

2 di Goro, being close to the shellfish farming ground, should be considered a "clean" site.

3 Unfortunately, there are no data about pre-industrial levels of copper in the Sacca. However,

4 from the $1980 \mathrm{~s}$, an increased concentration of copper in the water (up to $7 \mu \mathrm{g} \mathrm{Cu}{ }^{-1}$ ), SPM

5 (up to $250 \mu \mathrm{g} \mathrm{Cu} \mathrm{g}^{-1}$ ) and sediment (up to $50 \mu \mathrm{g} \mathrm{Cu} \mathrm{g}^{-1}$ ) is evident. Moreover, sedimentary

6 copper concentrations were often above the threshold effect level (TEL: $18.7 \mu \mathrm{g} \mathrm{Cu} \mathrm{g}{ }^{-1}$ ) and

7 effect range Low (ERL: $34 \mu \mathrm{g} \mathrm{Cu} \mathrm{g}^{-1}$ ) of the Florida Department of Environmental Protection

8 (FDEP; MacDonald, 1994) and the National Oceanic and Atmospheric Administration

9 (NOAA; Long et al., 1995) sediment quality guidelines respectively. Copper is known to preferentially adsorb to organic matter, and such an adsorption might reduce the reactivity and

11 hence the toxicity of copper (Gardner and Ravenscroft, 1991). Clams, however, can

12 accumulate contaminants directly from seawater, from sediments and from contaminated food

13 (Coelho et al., 2002a; 2002b; Coughlan et al., 2002). Such accumulation can result in the

14 production of initiators of cytotoxic injury with degeneration of lysosomal function (Kurelec,

15 1993), decreased scope for growth, as shown by the present study, faster aging, and finally, decreased reproduction which reduces the fecundity of the population (Coughlan et al., 2002).

Most bivalves can reduce the toxic effects of metals by producing metal-binding proteins (Roesijadi, 1980). However, the increased energy expenditure recorded in the $\mathrm{Cu}$ exposed clams was probably due in part to the increased cost of metal-binding protein synthesis. When combined with the reduction in food energy consumption, due to the toxic

21 effects of copper on the ciliary feeding activity, this resulted in very low and even negative 22 values of scope for growth in $10 \mu \mathrm{g} \mathrm{Cu} \mathrm{l}^{-1}$ exposed clams. Even at the end of the $20 \mathrm{~d}$ 23 exposure period, when physiological responses seemed to recover slightly, the overall 24 energetics of the clams was still greatly affected. This suggests that any detoxification 25 mechanism allowed only partial recovery or only served to reduce the potential toxic effects 
1 of $\mathrm{Cu}$ exposure. In fact, at the end of the $20 \mathrm{~d}$ long exposure, clearance rates were, on average,

$254 \%$ of control rates, respiration was high at about $120 \%$ of control, and scope for growth was

3 reduced to about $15 \%$ of the initial value. These figures are in accordance with Sobral and

4 Widdows (1997), who studied the effect of copper on the clam Ruditapes decussatus. It has

5 been suggested (Hawkins et al., 1989) that a positive relationship may exist between the

6 growth rate of individual bivalves and heterozygosity measured at polymorphic enzyme loci.

7 In the blue mussel (Mytilus edulis), exposure to copper in the laboratory revealed genotype-

8 dependent mortality, with those individuals expressing a higher degree of heterozygosity

9 surviving longest (Hawkins et al., 1989). The hypothesis that heterozygosity is associated with improved survivorship in contaminated conditions is also supported by Nevo et al.

11 (1986), who reported that for marine molluscs, broad-niche and highly heterozygous species

12 display significantly higher survivorship than narrow-niche, genetically poor, congeneric

13 species, after exposure to inorganic pollutants. Unfortunately, the level of heterozygosity of

14 Adriatic Tapes philippinarum populations is unknown. However, considering that all Adriatic

15 populations, from Venice to Ravenna, derive just from three successive introductions (1984,

161985 and 1986) of only about $20 \mathrm{~kg}$ of seed imported from the same British hatchery

17 (Pellizzato, 1990), it seems reasonable to suspect that the level of heterozygosity should not

18 be particularly high. The increasing environmental levels of copper, as well as other toxic

19 environmental contaminants, poses a threat to populations with reduced heterozygosity and

20 how it will affect the species' fitness and distribution.

21 In summary, the data presented in this study give sufficient concern about possible 22 environmental damage to further justify restrictive legislation for copper use in antifouling 23 coating. A strict interpretation of the precautionary principle might suggest that more rigorous 24 regulatory action to control copper inputs in the field would be justified. 


\section{ACCEPTED MANUSCRIPT}

\section{Acknowledgemets}

2 This study was supported by Regione Emilia Romagna (2376/2002). We are grateful to A.

3 Pagnoni (Dept. of Chemistry, University of Ferrara) for copper analyses. J. Widdows and an

4 anonymous reviewer are acknowledged for constructive criticism. 


\section{References}

2 Bayne, B.L., Thompson, R.J., Widdows, J., 1976. Physiology: I. In B.L. Bayne, Marine

3 mussels: their ecology and physiology. IBP 10 (pp. 121-206). Cambridge University $4 \quad$ Press.

5 Coelho, M.R., Bebianno, M.J., Langston, W.J., 2002a. Route of TBT uptake in the clam

Conover, R.J., 1966. Assimilation of organic matter by zooplankton. Limnology and

Coughlan, B.M., Hartl, M.G.J., O’Reilly, S.J., Sheehan, D., Morthersill, C., van Pelt,

Fagioli, F., Landi, S., Locatelli, S., Vecchietti, R., 1991. Valutazione del carico di metalli nelle acque, nei sedimenti e nei principali organismi accumulatori. In Studio integrato sull'ecologia della Sacca di Goro (pp. 135-172). Franco Angeli Milano.

Freedman, J.H., Ciriolo, M.R., Peisach, J., 1989. The role of glutathione in copper 21 metabolism and toxicity. Journal of Biological Chemistry 264, 5598-5605.

22 Gardner, M.J., Ravenscroft, J.E., 1991. The range of copper complexing ligands in the Tweed estuary. Chemical Speciation and Bioavailability 3, 22-29. 
1 Geret, F., Serafim, A., Barreira, L., Bebianno M.J., 2002. Response of antioxidant system to

2

3

4 copper in the gills of the clam Ruditapes decussatus. Marine Environmental Research 54, 413-417.

Gnaiger, E., 1983. Calculation of energetic and biochemical equivalents of respiratory oxygen consumption. In E. Gnaiger \& H. Forstner, Polarographic oxygen sensors (pp. 337-345). Springer-Verlag, Berlin.

Gnassia-Barelli, M., Romeo, M., Puiseux-Dao, S., 1995. Effects of Cadmium and Copper contamination on Calcium content of the bivalve Ruditapes decussatus. Marine Environmental Research 39, 325-328.

Goulletquer, P., Heral, M., 1997. Marine molluscan production trends in France: from fisheries to aquaculture. NOAA Tech. Report NMFS 129, 137-164.

Hawkins, A.J.S., Rusin, J., Bayne, B.L., Day, A.J., 1989. The metabolic/physiological basis of genotype-dependent mortality during copper exposure in Mytilus edulis. Marine Environmental Research 28, 253-257.

Helland, A., Bakke, T., 2002. Transport and sedimentation of $\mathrm{Cu}$ in a microtidal estuary, SE Norway. Marine Pollution Bulletin 44, 149-155.

IREPA, 2003. Osservatorio economico sulle strutture produttive della pesca marittima in Italia 2001-2002. XI Rapporto. Franco Angeli Milano, 360 pp.

Isani, G., Monari, M., Andreani, G., Fabbri, M., Carpenè, E., 2003. Effect of copper exposure on the antioxidant enzymes in bivalve mollusc Scapharca inaequivalvis. Veterinary Research Communications 27, 691-693.

Karlsson, J., Eklund, B., 2004. New biocide-free antifouling paints are toxic. Marine Pollution Bulletin 49, 456-464.

Kurelec, B., 1993. The genotoxic disease syndrome. Marine Environmental Research 35, $341-348$. 
1 Long, E.R., Field, L.J., MacDonald, D.D., 1995. Predicting toxicity in marine sediments with numerical sediment quality guidelines. Environmental Toxicology and Chemistry 17, 714-727.

MacDonald, D.D., 1994. Approach to the assessment of sediment quality of Florida coastal waters. Vol. I - Development and evaluation of sediment quality assessment guidelines. Florida Department of Environmental Protection, Tallahassee FL, 126 pp.

Manley, A.R., 1983. The effects of copper on the behaviour, respiration, filtration and ventilation activity of Mytilus edulis. Journal of the Marine Biological Association of UK 63, 205-222.

Matthiessen, P., Reed, J., Johnson, M., 1999. Sources and potential effects of copper and zinc concentrations in the estuarine waters of Essex and Suffolk, United Kingdom. Marine Pollution Bulletin 38, 908-920.

Mistri, M., 2004. Effects of Musculista senhousia mats on clam mortality and growth: much ado about nothing? Aquaculture 241, 207-218.

Nevo, E., Noy, R., Lavie, B., Beiles, A., Muchtar, S., 1986. Genetic diversity and resistance to marine pollution. Biological Journal of the Linnean Society 29, 139-144.

Okamura, H., Watanabe, T., Aoyama, I., Hasobe, M., 2002. Toxicity evaluation of new antifouling compounds using suspension-cultured fish cells. Chemosphere 46, 945-951.

Pellizzato, M., 1990. Chapter 8: Acclimatization of the Tapes philippinarum species and the first experimental rearing basins in Italy. In Tapes philippinarum: Biologia $e$ Sperimentazione (pp. 115-140). Ente Sviluppo Agricolo Veneto.

Riisgård, H.U., Kittner, C., Seerup, D.F., 2003. Regulation of opening state and filtration rate in filter-feeding bivalves (Cardium edule, Mytilus edulis, Mya arenaria) in response to low algal concentration. Journal of Experimental Marine Biology and Ecology 284, 105-127. 
1 Roesijadi, G., 1980. Influence of copper on the clam Protothaca staminea: effects on the gills 2 and occurrence of copper-binding proteins. Biological Bulletin 158, 233-247.

3 Schiff, K., Diehl, D., Valkirs, A., 2004. Copper emissions from antifouling paint on

Sgro, L., Munari, C., Angonese, A., Basso, S., Mistri, M., 2005a. Functional responses and scope for growth of two non-indigenous bivalve species in the Sacca di Goro (northern

Sgro, L., Mistri, M., Widdows, J., 2005b. Impact of the infaunal Manila clam, Ruditapes

White, S.L., Rainbow, P.S., 1985. On the metabolic requirements for copper and zinc in Molluscs and Crustaceans. Marine Environmental Research 16, 215-219. 
1 Widdows, J., Staff, F., 1997. Practical procedures for the measurement of scope for growth.

2 Plymouth Marine Laboratory Edition, Plymouth.

3 Yebra, D.M., Kiil, S., Dam-Johansen, K., 2004. Antifouling technology-past, present and 4 future steps towards efficient and environmentally friendly antifouling coatings. $5 \quad$ Progress in Organic Coating 50, 75-104. 


\section{$1 \quad$ Figure Legends}

2

3 Figure 1. Mean clearance rates (CR) by clams (Tapes philippinarum) in response to $\mathrm{Cu}$ exposure $\left(10 \mu \mathrm{g} \mathrm{Cu}^{-1}\right)$ and control conditions (mean $\left.\underline{\mathrm{SD}}\right)$.

5 Figure 2. Mean rates of oxygen consumption by clams (Tapes philippinarum) in response to $\mathrm{Cu}$ exposure $\left(10 \mu \mathrm{g} \mathrm{Cu}^{-1}\right)$ and control conditions (mean $\left.\pm \mathrm{SD}\right)$.

7 Figure 3. Mean absorption efficiency (AE) by clams (Tapes philippinarum) in response to $\mathrm{Cu}$ exposure $\left(10 \mu \mathrm{g} \mathrm{Cu}^{-1}\right)$ and control conditions (mean $\left.\pm \mathrm{SD}\right)$.

9 Figure 4. Scope for growth for control and exposed clams (Tapes philippinarum) at each measurement period. 


\section{ACCEPTED MANUSCRIPT}
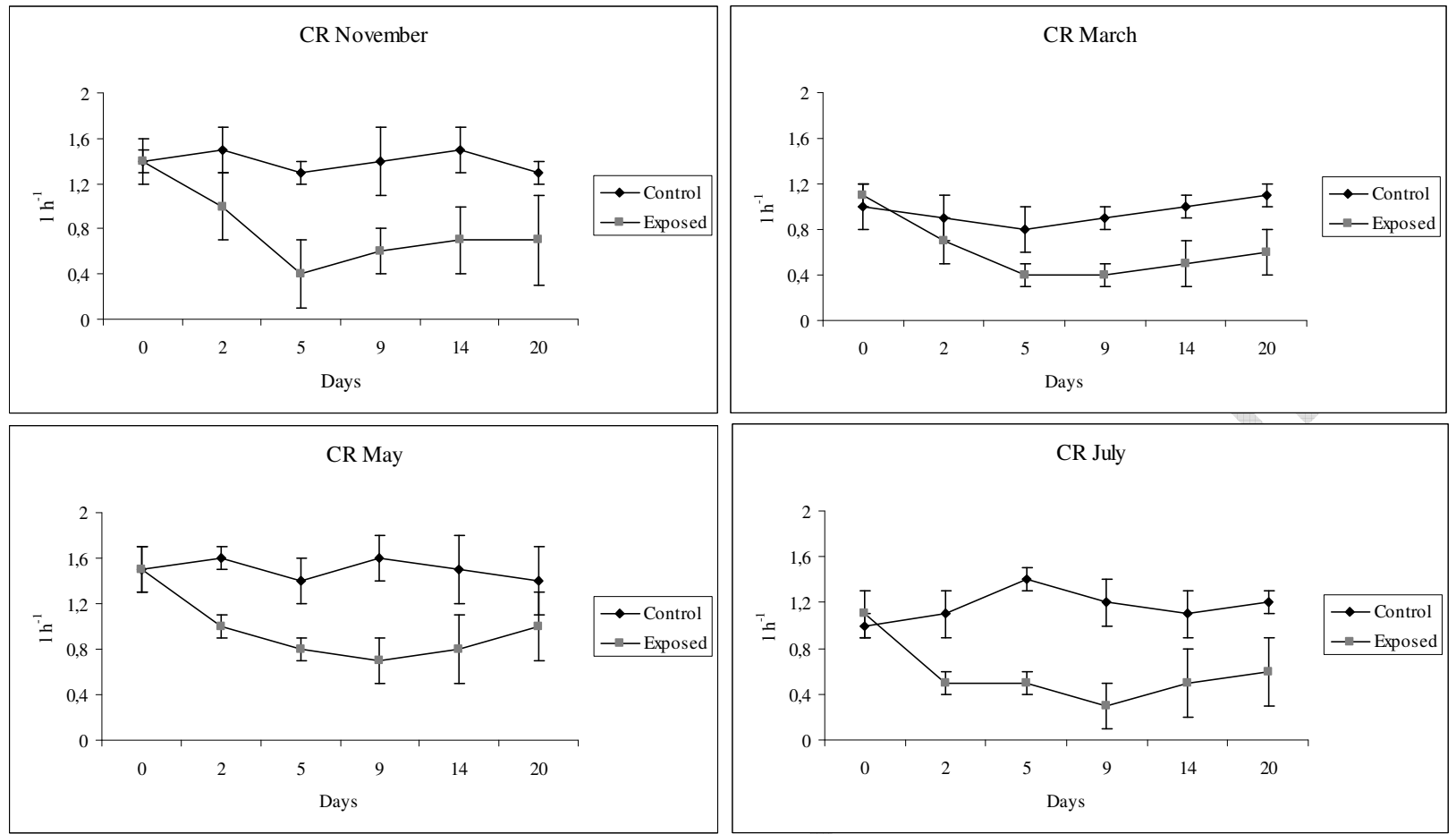

Figure 1 


\section{ACCEPTED MANUSCRIPT}
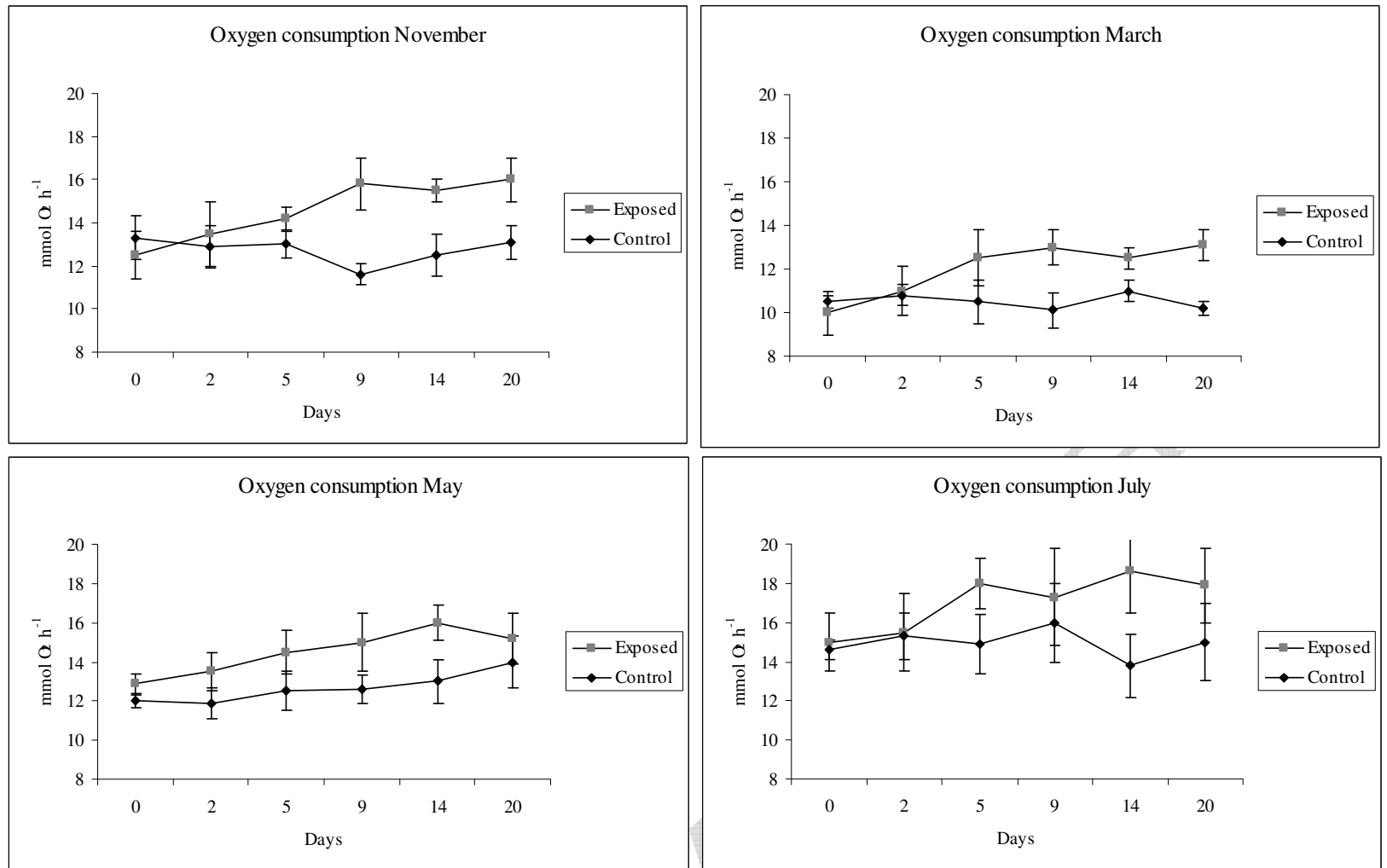

Figure 2 


\section{ACCEPTED MANUSCRIPT}
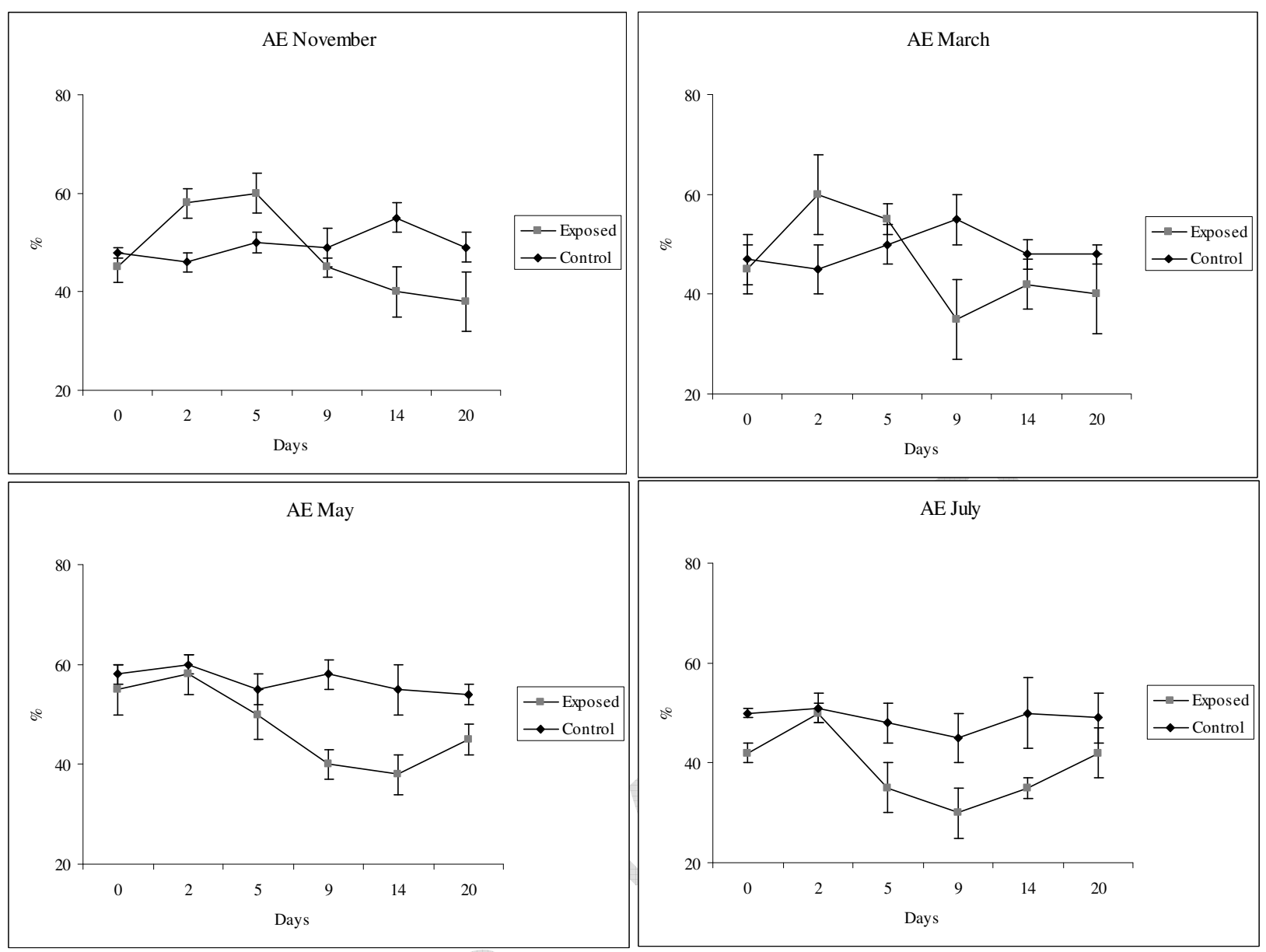

Figure 3 


\section{ACCEPTED MANUSCRIPT}
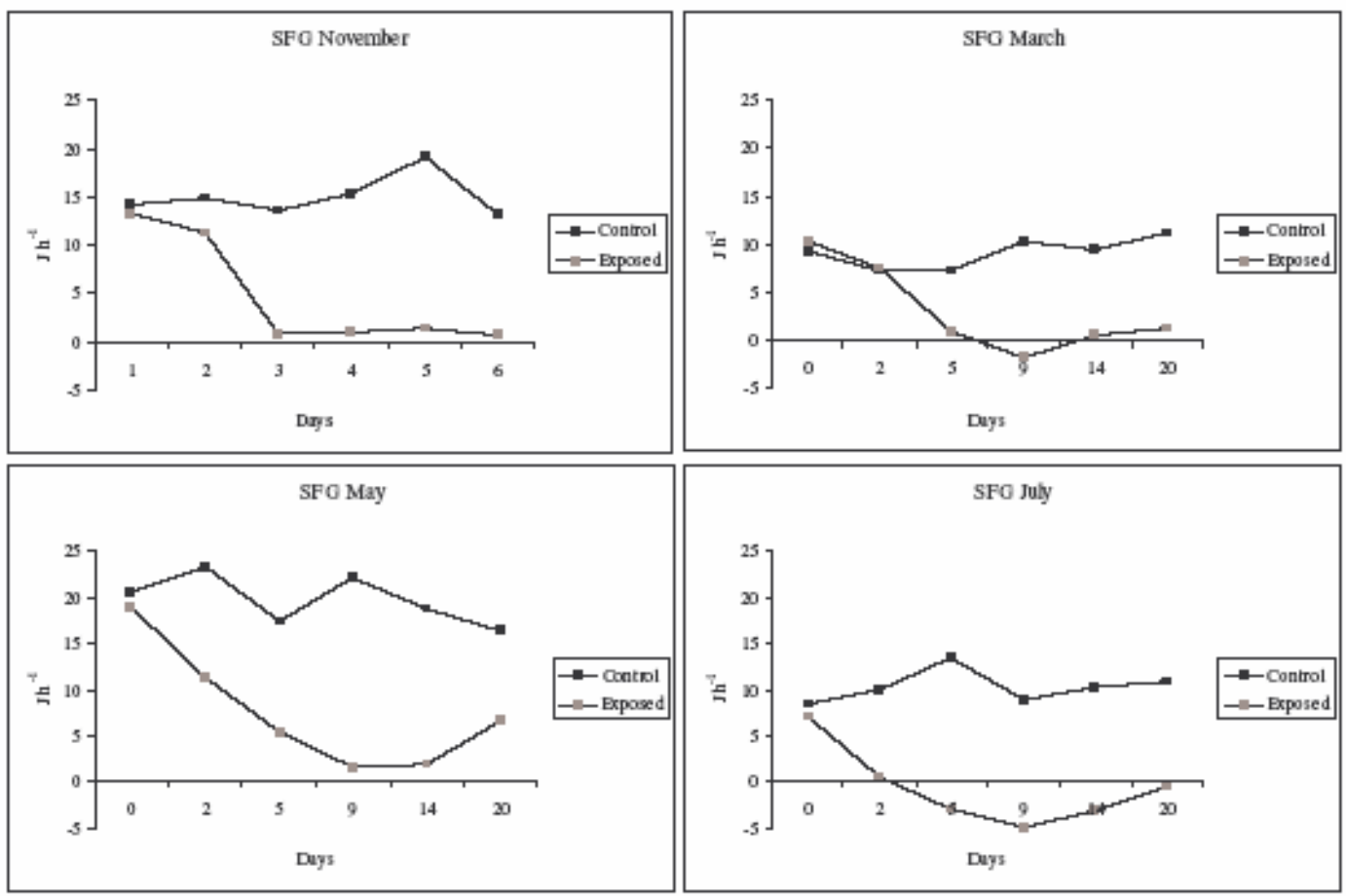

Fig 4 
Table 1

Results of ANOVA (F values) for physiological measurements.

Significancy: $* * *: \mathrm{p}<0.001 ; * *: \mathrm{p}<0.01 ; *$ : $\mathrm{p}<0.05$.

\begin{tabular}{|c|c|c|c|c|}
\hline & Nov & Mar & May & Jul \\
\hline \multicolumn{5}{|c|}{ Clearance rates } \\
\hline Time & $7.9 * * *$ & $8.8 * * *$ & $10.5^{* * *}$ & 2.4 \\
\hline Treatment & $189.4 * * *$ & $106.7 * * *$ & $204.1 * * *$ & $110.2 * * *$ \\
\hline $\mathrm{T} \times \mathrm{T}$ & $7.9 * * *$ & $8.6 * * *$ & $11.5 * * *$ & \\
\hline \multicolumn{5}{|c|}{ Oxygen consumption } \\
\hline Time & 1.6 & 1.6 & $8.1 * * *$ & $9.1 * * *$ \\
\hline Treatment & $5.3^{*}$ & $60.1 * * *$ & $55.8 * * *$ & $99.2 * * *$ \\
\hline $\mathrm{T} \times \mathrm{T}$ & 1.1 & $4.9 * *$ & 0.8 & $8.6 * * *$ \\
\hline \multicolumn{5}{|c|}{ Absorption efficiency } \\
\hline Time & $7.1 * *$ & $6.8 * *$ & $9.8 * * *$ & $10.4 * * *$ \\
\hline Treatment & $4.3 *$ & $8.3 * *$ & $65.6 * * *$ & $88.4 * * *$ \\
\hline $\mathrm{T} \times \mathrm{T}$ & $10.9 * * *$ & $12.2 * * *$ & $2.7 *$ & $3.3^{*}$ \\
\hline
\end{tabular}


Table 2

Values of copper concentration (mean \pm standard deviation) at the study site.

\begin{tabular}{lccc}
\hline & $\begin{array}{c}\text { Water } \\
\left(\mu \mathrm{g} \mathrm{Cu} \mathrm{l}^{-1}\right)\end{array}$ & $\begin{array}{c}\mathrm{SPM} \\
\left(\mu \mathrm{g} \mathrm{Cu} \mathrm{g}^{-1}\right)\end{array}$ & $\begin{array}{c}\text { Sediment } \\
\left(\mu \mathrm{gu} \mathrm{g}^{-1}\right)\end{array}$ \\
\hline February & $3.3 \pm 0.2$ & $108.1 \pm 4.0$ & $16.4 \pm 1.5$ \\
March & $3.0 \pm 0.2$ & $187.7 \pm 4.7$ & $46.3 \pm 5.5$ \\
April & $2.0 \pm 0.1$ & $101.0 \pm 3.5$ & $21.9 \pm 4.0$ \\
May & $3.2 \pm 0.2$ & $100.7 \pm 4.5$ & $15.0 \pm 3.2$ \\
June & $7.3 \pm 0.2$ & $74.3 \pm 2.1$ & $7.5 \pm 2.0$ \\
July & $3.5 \pm 0.1$ & $70.0 \pm 2.5$ & $8.6 \pm 2.2$ \\
August & $\mathrm{ND}$ & $\mathrm{ND}$ & $\mathrm{ND}$ \\
September & $\mathrm{ND}$ & $\mathrm{ND}$ & $\mathrm{ND}$ \\
October & $3.0 \pm 0.3$ & $100.5 \pm 4.0$ & $18.0 \pm 4.6$ \\
November & $2.5 \pm 0.2$ & $201.6 \pm 5.8$ & $26.3 \pm 3.7$ \\
December & $4.7 \pm 0.2$ & $287.3 \pm 6.0$ & $53.5 \pm 10.1$ \\
\hline
\end{tabular}

